\title{
Taking Back Control of Nothing: Elites Denouncing Elites to Mobilize Populism in the Service of Power - from NAFTA to Trump, Brexit, and the EU
}

\author{
Christian Garland
}

\section{Introduction}

The title of this article begins with the favorite slogan of the UK Brexit campaign Taking Back Control but subverts its populist rhetoric with the addendum... of nothing. The article critically analyzes the top-down ideological substance of Brexit as well as drawing the distinct parallels with the Trump US presidency, these being a lowestcommon-denominator populism of elites denouncing elites, but this presented as if it were from below and the will of the people. Brexit is a portmanteau of "British exit," and is something of a catchall for the complexities of the UK leaving the EU, and indeed the febrile political climate in the UK of the past three years. "Brexiters" as it is used in the article refers to those who maintain that the UK must leave the EU at any cost and who continue to push this as both necessary and desirable. The article uses these terms to identify those in the "Leave" camp who campaigned for the outcome which also resulted in a narrow victory for "Leave" that is, in the outcome of "Brexit," but does not also include all of those who may have voted for such an outcome.

The Brexiters' rhetoric has succeeded in mystifying a substantial section of what Thomas Frank calls "Rust Belt Britain"1 similar to Trump's own crudely inchoate populism to mobilize a section of the US electorate which feels similarly ignored by Washington. At its worst, this has sought to tap into arbitrary collective identities of race and nation, willfully ignoring if not accepting the endorsement of the far-right.

Indeed, populism and traditionalism along with nationalism crossing into fascism, make use of pre-modern tribal loyalties based on race and where someone is from. For these being the go-to program for state leadership for the last two centuries, it has been a case of as and when depending on efficacy and locale of incumbent elites. Populism and traditionalism and all of the reactionary and conservative tribal loyalties these tap into are inherently opportunist, and it could be argued that tapping into them is the primary reason why the reaction of the last three years has been so successful in the top-down mobilization of the base by outliers of the same elites that are superficially denounced.

In the US, NAFTA which was of course signed off by Bill Clinton in the early-90s, was in many ways the paradigm example of Neoliberal Globalization in legislative form, similarly the EU's own fatally flawed commitment to its version of that can be seen in practice in the Troika's austerity punishment of Greece, and in many of the EU's core founding documents.

This article aims to incise the rhetoric of the Trump administration critically and indeed the fallacious ideological claims of the - mostly right-wing conservative - Brexiters who it must be said, inhabit their own fantasy world of a Merrie England that never was. 


\section{Legislating the "vile maxim"2 of neoliberalism: historicizing NAFTA}

Noam Chomsky writing in 1993 on the North American Free Trade Agreement (NAFTA) and its expected consequences cited Adam Smith's invocation of "the vile maxim of the masters of mankind": "All for ourselves, and nothing for other People"3 to illustrate the instrumental logic of the US-led agreement between states and corporations to render all resources, raw materials, and indeed labor the length and breadth of North America subject to free trade. This of course meant that what at the time had been 15 years of neoliberalism ${ }^{4}$ was enshrined in a supranational trade agreement to allow all public goods to be marketized and quantified with a market value, just as labor would have to be made flexible, that is, individualized accordingly and any capacity for collective action rendered all-but impossible: the US in open contradiction of its own edicts as well as those of NAFTA also practiced its own version of protectionism - as it saw fit, for itself but not other countries in the agreement.

Above all else, NAFTA ${ }^{5}$ encouraged and facilitated the outsourcing of jobs primarily though not exclusively manufacturing from the US to Latin American countries and Mexico in particular - and could indeed be viewed 25 years from its inception as paradigmatic of Neoliberal Globalization ${ }^{6}$ : predicated as it is on economic orthodoxy or what is also called Neo-Classical economics. ${ }^{7}$ As such, in the populist tumult of the past five years, the incumbent US president Donald Trump has - so far - successfully presented himself and his vaudeville act as being representative of the hopes and fears of suburban and rural America, and the Republican Party has successfully managed to do what Thomas Frank describes thus "Republicans successfully inverted their historical brand-image as the party of the highborn, remaking themselves as plain-talking pals of the forgotten people who had so spurned them during the Great Depression. Republicanism's payload, however, was the same as it had been in 1932. Just look at what conservatism proceeded to do to those average people once they welcomed it into their lives."

Trump's rhetoric, in the worst traditions of reactionary populism, has made cynical use of tapping into existing prejudices of its target electoral demographic and the ignorance fuelling those, in one sense a win-win game plan, using the same unprovable confirmation bias as conspiracy theory which it also unsurprisingly utilizes. ${ }^{9}$ This section of the article mostly aims as the subtitle says to historicize NAFTA to help trace its background and the last 25 years of its existence to set out the contemporary political context better, so segueing into the nonsensical claims of the US president should not be seen as more than that, a minor excursus.

In the early-90s at the time it first came into being NAFTA was to portend globalized multinational capitalism at The End of History ${ }^{10}$ that is, as agreed by multinational corporations and legislated by interchangeable politicians from interchangeable political parties. More than three decades later, after NAFTA first appeared as a signature piece of glib "post-political11 macroeconomic policy prescription, and after the significant challenge of the "antiglobalization" / "alter-globalization" movement of the late- $90 \mathrm{~s}^{12} /$ early-2000s ${ }^{13}$ the wholesale crisis of what became the Great Recession in 2007/2008 in part at least, upended such formerly bland policy assumptions, albeit the response of politicians, governments and para-state institutional bodies was mostly what could be described as Neoliberalism with Keynesian Characteristics, indeed as Chomsky notes “'free-market capitalism' is to be risk free for the masters, as fully as can be achieved."14

The early-90s consensus of political and financial elites on NAFTA, and the neoliberal policy models of the International Monetary Fund (IMF), World Bank, and G7, as well as the annual (self) congratulation of the World Economic Forum in Davos, found considerable ideological succor in the triumphalism of the end of the Cold War which the West had apparently won. The fall of the Berlin Wall in 1989, and with it German reunification, the collapse of Soviet satellite states, and the final confirmation of this with the collapse of the Soviet Union itself in 1991 underlined Fukuyama's End of History thesis it seemed. By the end of the decade and the end of the Twentieth Century, however, serious fissures had begun to appear. ${ }^{15}$ The "anti-globalization/alter-globalization" mobilizations which found their first major public expression with the 1999 Seattle anti-WTO mass mobilization, and then throughout the early-2000s, albeit largely eclipsed by $9 / 11$ and subsequent Islamist/Jihadist attacks and the War on Terror over the next two decades, were favored to the extent that they involved hundreds of thousands of people at their height, but hundreds of thousands of those already more or less politicized, and for all their many contradictions, were not what could be called populist: then or now. These events and the highly politicized actors who oriented them were infused by the necessity for trying to define a version of deliberative, direct democracy in their organizational practices or means, besides the ends these were aiming for, those being radically progressive social change from below.

The time of the "movement of movements" of the late-90s/early-2000s, was otherwise mostly one of economic equilibrium and relative social and political peace in the countries of the First World or Global North, specifically 
those of the West: the US, UK, and Continental Europe. Nascent discontent was confined to the margins, and although sections of the general population of these societies may not have benefited from the promissory claims of their political classes and were aware of it, this was also the time of New Labor in the UK and similar incarnations across Continental Europe. In the US, George W. Bush consolidated his surprise presidential win in 2000, winning a second term in 2004 the Crisis of the late-2000s hitting in his last eighteen months of office, and although the US where it originated felt the effects at their most severe ${ }^{16,17}$, its economy recovered faster than that of the UK whose own anemic recovery was far less apparent; in the EU in particular southern Europe, the Great Recession manifested in a further phase as the European Sovereign Debt Crisis, as states socialized private debt to refinance loans by bailing out banks and other financial institutions as in the UK and US but so too public borrowing from institutional lenders, the caveat being savage Austerity and cuts to every area of the public sector, Greece more than any other country continuing to suffer the diktats of the Troika: the European Commission (EC), European Central Bank (ECB), and the IMF, who demanded unending cuts and Austerity as the price for needing funding in the form of borrowing by the state. ${ }^{18}$

At the time of the Sub-Prime Crisis in 2007, which became a full-blown Financial Crisis over the next 12 months, there was no mass movement from below, or broadly speaking from the left by way of response. In neither the US or the UK where the contagion of the "Credit Crunch" of the economic crisis was felt instantaneously in 2007 as it was in its next phase in 2008, there were some signs of widespread anger, ${ }^{19}$ and some left response, but these remained relatively inchoate. ${ }^{20}$ By this is meant what was largely absent was an awareness of the reasons for the social consequences and consciousness of the class in society responsible for all of those and indeed the Crisis itself who while being protected from its knock-on effects in their entirety, also profited from these from the very start. State intervention to shore up banks deemed "too big to fail" took the form of course of the takeover of the government-sponsored Fannie Mae and Freddie Mac by the Federal Reserve and industrial enterprises such as General Motors and Chrysler in the US filing for Chapter 11 Bankruptcy as well as de facto nationalization. In the UK banks including Lloyds-TSB, Royal Bank of Scotland, and the Halifax all had the state acquiring majority ownership, as it had done to no avail in trying to prop up the heavily indebted Northern Rock in September 2007, whose value was mostly on paper if not overwhelmingly comprised of Fictitious Capital in the form of the toxic assets of unpaid and unpayable Sub-Prime mortgages through its US interests and the no less toxic assets of Iceland's Ice Save owned by Landsbanki.

In the decade since the late-2000s Crisis in its various formative stages of progression and the societal consequences foremost among these being unending Austerity administered by governments of all shades in countries across the EU, there has been little in the way of class analysis or even of the power relations at work: those being a massively unequal power differential of financial and economic elites wielding undue power over the rest of society to their advantage. To be sure, the left - such as it is - cannot be held solely responsible for the populist turn of the last five years, and it should be remembered that in the use of this shorthand is meant in thoroughly unorthodox Marxist terms. ${ }^{21}$ Such an analysis calls into question the whole of existing society itself, and can identify its problems but does not pretend to offer instant quick-fix solutions to them, it also makes high demands of people: of both their intelligence and their capacity for empathy, unlike right-wing populism and fascism, and unlike them it does not find groups for apportioning blame and setting itself apart from.

In setting out the contemporary political context, this section of the article has endeavored to historicize NAFTA to better understand how the signature piece of early-90s neoliberal macro-economic trade policy which first came into being in 1994, embodies the post-political institutional policy assumptions of neoliberalism. Twenty-five years later in a state of ongoing crisis, political and economic elites are superficially denounced in the populist backlash which makes use of its own ideology's reactionary account of people, society and the world to supposedly explain them for its passive and inert target demographic who simply want answers they can believe and repeat regardless of how nonsensical or fallacious these may be: respectively, in the US those at Trump rallies wearing red Make America Great Again baseball caps, and in the UK those who voted for Brexit and believe the country crashing out of the EU with no deal is both necessary and desirable.

\section{Make America Great Again...with populist demagoguery and nationalism}

The incumbent US president Donald Trump won the 2016 presidential election on a populist ticket of "Make 
America Great Again," unexpectedly running for president as one of 17 Republican nominees, his winning the election was no less of a surprise. In the period up to early 2019, a continually changing assemblage of White House appointees have been either sacked or quit. ${ }^{22,23}$ Trump's appeal is above all else to his base, and there is the belief among both this demographic base and his aides that a second term can be secured - thus necessarily winning an electoral majority taking in enough undecided voters by nudging them whether to vote for him again or for the first time by ramping up much of what is viewed as behavior beyond the pale for a public figure or that of a US president. Armed with his smartphone, the president's love of Twitter is like a child with a new toy his tweets being indicative of behavior unbecoming of a US president, but this just further boosting his appeal for supporters.

The long list of instances of behavior beyond the pale for a public figure or that of a US president is now so long it has been detailed in a database compiled by The New York Times ${ }^{24}$ and although just a few of the 567 instances detailed would very likely spell the end of any other US president, for Trump supporters it confirms why they support him: "He tells it like it is" and "Isn't afraid of upsetting anyone," seeing this as cocking a snook to Washington insiders and East Coast elites. Trump presents himself as being for the "Other America" of forgotten post-industrial towns in the Rust Belt and impoverished - white - suburbs without employment or hope - both of which he claims to offer, as Deakin University Associate Prof Matthew Sharpe notes thus "He never seems to express any doubts. He turns complex problems into simple equations: build a wall, nuke ISIS. Simplistic, but compelling" ${ }^{25}$ giving simple answers to complex problems but as US president, the most powerful man in the world, Trump "emotionally reassures his supporters." ${ }^{26}$ Donald Trump has said "I love the poorly educated," 27 not adding that this is because they will believe anything he says or tells them.

A big part of the emotional reassurance Trump offers his supporters feeds into their hopes and fears, tapping into these by playing up to existing prejudices and willful ignorance by framing these as common sense and something the president's plain speaking connects with and reflects. In having successfully projected this image, the Trump White House has, with glacial cynicism, made use of all sorts of nonsensical and defamatory claims about its opponents and critics, using various conspiracy theories - which are always unprovable either way - to confirm the confirmation bias of those who already had the same or similar views.

Of the now-defunct British political consultancy, Cambridge Analytica ${ }^{28}$ which was hired by the Trump presidential campaign to harvest personal data from social media expertly distilled both its own and the Trump campaign's instrumental logic when former Managing Director of the company Mark Turnbull, was caught on camera saying "It's no good fighting an election on facts, it's about emotion and hopes and fears", 29 secure in the knowledge that "many of those are unconscious." ${ }^{30}$ Elaborating further, "It has to happen without anyone thinking it is propaganda because the moment you think 'that is propaganda' the next question is: 'whose put that out?"' 11 Former Cambridge Analytica CEO Alexander Nix, in the final interview of the series of interviews secretly recorded by Channel 4 further effectively summed up the tactics of the now-defunct company a co-founder of which was Steve Bannon, with what also became the title of the short online article cited in this longer one, "It needn't be true as long as it's believable." ${ }^{32}$ Trump's pandering to lowest common denominator hearsay and rumor-mongering makes use of the term "fake news" which was initially coined to describe the output of right-wing online publications and websites such as Breitbart News - another outlet Bannon helped co-found - which continue to present opinion pieces as if they were straightforward fact, as opposed to opinion, along with promoting conspiracy theories in the same terms.

The Trump White House could be seen as a very opportunist in terms of the tactics it is prepared to use in its strategy for retaining power. By this is meant it sees nothing problematic in contradicting itself and then doubling back on itself ${ }^{33}$ at every turn. Trump and his appointees also display the same combination of jaw-dropping hubris and cynicism along with outright stupidity: the invention of "alternative facts" 34 being just one of the most wellknown examples, the other being the readiness to call anyone or anything critical of the Trump White House fake news. Fake news meaning anything and everything critical of Trump or anything he says, just as issuing nonsensical statements not based in fact but contradicted by it, that is, objective reality is claimed merely to be a variation of it, in the same way, $2+2=5$ and black is white and white is black.

In keeping with its use of instrumental reason to achieve whatever it deems necessary or desirable - the retention of political power above all else - the Trump White House also sees nothing wrong in accepting the endorsement of the far-right and alt-right, the latter it should be said is simply a politically savvy cultural re-branding of the former. The far-right and its re-branded "alt" face, is in the terms of fascism inherently opportunist and will do anything to expand its influence, the "alt-right" operating online as much as in the non-virtual world waging a cultural war as 
much as anything making use of all of the weapons at its disposal. This article is not devoted to an analysis of the "alt-right," but will nonetheless make some passing critique of its strange and unwelcome reactionary manifestations, since they are both supportive of Trump and examples of it seeking to expand its influence in the populist backlash visible in the US and to differing extents the UK and Continental Europe. Besides different actual fascist and/or neo-Nazi groups endorsing Trump including the Ku Klux Klan, the culture wars waged by the different faces of the "alt-right" provide two standout examples: those sexually frustrated males who call themselves "Incels" 35 - who find themselves forced to practice involuntary celibacy because they believe feminism means no women are prepared to sleep with them - or unsurprisingly perhaps, talk to them. The reason why this example of the alt-right is prescient to the article, is because it is something relatively recent that has gained traction in the fringes of the right-wing base in roughly the last five years, which is also the timeframe of the populist backlash and the climate it has helped create, and which both Trump and Brexit embody.

The other manifestation of the cultural reach of the alt-right has some similarity with Incels, this being "pick up artists" literally men styling themselves as having the answers and sharing the secrets with other sexually frustrated and gullible men of how to get laid, making use of a profoundly troubling veneration and promotion of what has been described accurately as toxic masculinity. ${ }^{36}$ This tawdry scam along with seeing patriarchy, traditional sexual roles, and misogyny as natural inevitable and immutable, sees sex as something done by the active male to the passive and servile female, just as all male-female relations are an adversarial contest in which the alpha male wins with conquest: the "alt-right" like fascism being big on pseudoscience, in this case taking a term from zoology and applying it to society, no longer remaining scientific at all but become Social Darwinism or sociobiology, that is, ideology. This again finds an at the very least uncritical if not accepting often welcoming home in more established conservative and neo-conservative groupings, which threw in their lot with Trump becoming president.

The incumbent US president being prepared to accept and not explicitly disavow the endorsement of the farright was crystallized well in his slowness to condemn the murderous violence at the "Unite the Right" event in Charlottesville, Virginia on August 12, 2017, ${ }^{37}$ in which counter protestor Heather Heyer was killed by a member of the far-right driving his car straight into the crowd of anti-fascist counter-protestors. He offered instead that there were "very fine" people ${ }^{38}$ present and that there had been violence on many sides. Trump's reluctance to explicitly condemn the murderous act of James Fields Jr. has not been forgotten 18 months later in which Fields faced Federal indictment and was found guilty of First-Degree murder then sentenced to life in prison plus 419 years for ten additional charges. ${ }^{39}$

So while the far-right and its "alt" re-branding support the Trump presidency which has at the very least been reluctant to distance itself from this endorsement, the inchoate populism of Trump and his rallies is what provides the cover for the far-right to expand its sphere of influence, and which of course also bears some resemblance to the ritual and ceremony of fascism: what could be called "the aestheticization of politics." Another way of describing Trump's populism in a direct inversion of Marxism and indeed the substance of democracy and anything like socialism in which the masses become thinking-doing individuals exerting agency, is what can be described as the "aestheticization of the masses-as-masses." This lowest common denominator populism bases itself on the passivity and inertia of those responsive to it: reliance on a Strong Leader who will make difficult decisions and get things done because they are incapable of doing either. All that is required of 'Trump's supporters is enthusiasm for Trump, whooping and chanting and wearing MAGA red baseball caps, and believing whatever he says. ${ }^{40}$

Following the 2007/2008 Crisis and social fallout from the Crisis, by the mid-2010s, there was the beginning of the populist turn typified by the Trump presidential campaign and victory and the former UK prime minister David Cameron's misguided decision to hold a referendum on EU membership narrowly resulting in Brexit. This has also found form in populist and reactionary collective identities, none more so than nativism and nationalism, both of which the US and UK examples the subject of this article lend themselves to, and indeed are infused with.

What US liberals and the Democrats should try to comprehend, is their part in helping elect Trump. By this is meant that his presidency - fantastical as it may still seem - cannot be seen as completely from out of nowhere, and that Donald Trump of all the Republican presidential candidates was the one who gained the Republican nomination in 2016 says a lot about that party, as it does about the Democrats and their paucity of credible candidates - the possibilities and limits of Hilary Clinton and Bernie Sanders - notwithstanding.

As with the present populist tumult in both the US and UK and across Continental Europe, a not insignificant number of the many casualties of the "post-political" End of History neoliberal consensus agreed by their political classes has found in the disruption of the existing status quo by Trump, Brexit, and especially in Continental Europe 
the far-right what they feel offers them an "alternative". The veracity of the promises this "alternative" makes and these ever being realized is never seriously questioned. ${ }^{41}$

The fatally flawed "post-political" consensus of economic and political elites in the US and UK - and EU, over the last 25-30 years remains oblivious to how it could have contributed to the populist backlash embodied by Trump's presidency in the US and the terminal uncertainty of Brexit in the UK. Their assumptions are colored utterly by their class location, and they do not see how neoliberal globalization could have led to this. Theirs is Fukuyama's grey-on-grey technocratic worldview of capitalist society which accepts all of its social structures "as they are" and all of the homilies of neoliberalism including the claim of free market fantasists: the freer the market, the freer the democracy, and existence in these societies is that of Marcuse's One-Dimensional Man. Marcuse's original critique of One-Dimensional Man of the Twentieth Century understood that in a society in which social contradictions are flattened out into a wholly positive explanation of things, this is ideological and seeks as far as possible to eliminate even the capacity for critique, which is also applicable to its early Twenty-First Century incarnation, in which class consciousness is severely blunted at best, and atomized monads struggle to come together at all.

\section{Taking back control...of nothing: Brexit a tenuous narrative}

As populist reactions go, Brexit since 2016 and the ill-judged and hubristic whim of ex-prime minister David Cameron to call a referendum on the UK's membership of the EU, has thrown the future of all of the four countries comprising it into question. The referendum was a straightforward yes or no to the question, "Should the UK remain a member of the EU?" The absurdity of something with such long term economic, social and political consequences being decided by referendum has in the three years since, been spun with cynical confirmation bias by right-wing politicians and three right-wing tabloid newspapers as "The will of the people," ${ }^{, 2}$ a substantial number of these MPs always have made up at least a slight majority of Conservative MPs.

The result of "Leave" was most pronounced in what as this article notes, is Thomas Frank's description "Rustbelt Britain." ${ }^{43}$ In England and Wales depressed areas which heavy industry and manufacturing left forever 30 years ago, voted "Leave" by a 10\% margin, as did rural areas: the small university cities of Norwich and Cambridge the only places in the whole of East Anglia to return a vote for "Remain." The same pattern is observable in the rural West Country: Bristol a sizable city and the two small university cities of Bath and Exeter, were alone in an equally vast rural expanse of "Leave."

In the post-industrial Midlands and North of England the pattern of "Leave" by big sometimes vast margins was perhaps crystallized best by Stoke-on-Trent which returned a Leave vote of $69.4 \%$, a margin nearing $30 \%$. Stoke is a small city but comprised of six different towns all of which are economically depressed, the ceramics or pottery industry - the potteries- once having been the biggest employer in the city along with steel and coal mining in the surrounding county of Staffordshire in the northwest Midlands now replaced by precarious, insecure minimum wage jobs in Amazon fulfillment centers and underemployed minimum wage slavery in bookmakers and fast food outlets. Stoke also has a population that relies on food banks well above the national average.

In Stoke-on-Trent 60,000 people had been employed in the potteries industry as recently as the late 1970s, before manufacturing was largely switched to East Asia. In 2016 only 8,000 jobs were left. There, I walked past Stoke City's Bet365 stadium. Bet365, like most betting companies, relies on poorer people to generate a significant portion of its income. It had become Stoke's largest private employer. In a city where nearly $40 \%$ of households were living on less than GBP16, 000 a year and 3,000 were dependent on food banks, Bet365's owner Denise Coates was paying herself the equivalent of GBP594, 520 a day. 'There's a sense of powerlessness that pervades everything now', the local YMCA chief told me. 'People are waiting to be rescued.' But he knew it was a forlorn hope. ${ }^{44}$

Stoke is just one example - but there are many more - of a place where the population "make do as best they can" in the aftermath of 40 years of neoliberalism, practically speaking this means trying to make ends meet with intermittent minimum wage jobs very often this means underemployment and/or the de facto wage supplement of welfare of some kind; now wholly conditional on Catch-22 games of compliance. That places such as this and many others in England and Wales should have returned a "Leave" vote in such high percentages and by such margins, is disarming to many but should also not be seen simply as confirmation of what Brexiters wanted all along, or straightforward right-wing jingoism and xenophobia - although as with Trump as US president, there are certainly those who see the climate of Brexit as allowing them to make public their reactionary and racist leanings in ways that 
they would not have felt able to previously.

The UK of 2019 is a country which has suffered eight years of Austerity and successive Conservative or Conservative-led governments resolved to impose it. The coalition (2010-15) with some gusto set about a program of policies designed to benefit those in the top 10-15\%, and to make those below it believe that this was also for their benefit in keeping with neoliberal and conservative ideology: what could be called a version of Thatcherism redux. ${ }^{45}$ The practical results of Thatcherism redux have meant public services cut to the bone and all that entails: mass redundancies cuts, cuts and more cuts to everything in sight and charities expected to fill the social vacuum. Welfare -always minimal and increasingly punitive for decades - become an endurance assault course for the claimant the "sanctions regime" 46 meaning that they can and frequently do find their benefits cut off altogether by the Job Centre for the slightest pedantic reason, ostensibly for non-compliance with "the rules", and again being very much in keeping with the ideological worldview of the Tory party. ${ }^{47}$

Brexit has coalesced at the same time as the UK population - and a substantial section of the majority submerged from the view of Westminster - have continued to feel the structural violence of Late Capitalism, and as such is an inchoate and mistaken attempt to exert some sort of agency. Like the US, with which it has many similarities the UK bears an extraordinary resemblance to what Herbert Marcuse first defined in 1964 as One-Dimensional Society. The One-Dimensional society of 2019, and in its particular UK context is one which inculcates an ideology of passive acceptance and servility in its members from birth to death: everyday assumptions in its members for all of the commercial and institutional imperatives for the necessity and inescapable "reality" of "playing the game," a game it should be remembered which is rigged, but which all are nonetheless obliged to play and this always amounting to lose-lose for the conscripted player.

In the limbo of the last three years following the referendum result of 2016, Brexiters have repeated their slogan, "Take Back Control," ad infinitum in the tried and tested terms of propaganda. Brexit and the idiocy of the UK leaving the EU, of course, have not the slightest thing to do with taking back control of anything, but the slogan seeks to confirm the biases of those promulgating it and those repeating it.

The UK population as of February 2019 is $66,959,016 .^{48}$ According to the Office for National Statistics (ONS) the total number of parliamentary electors as of December 2016 was 45,766,429. In December 2015 it was $44,724,004 .{ }^{49}$ Of the total UK population in 2016 of $65,788,574^{50}$ besides all those who voted "Remain," those not on the electoral register were 18,090,999, and those who were but did not vote numbered 12,948,018, meaning $47,189,258^{51}$ did not vote "Leave" that is for Brexit in any form. The UK population has of course increased since 2016, but more notable still, is the fact that demographic changes in that timeframe mean at least 1.4 million young people who were too young to vote in 2016, are now 18 or over, ${ }^{52}$ this is matched by at least 1.5 million "Leave" voters now deceased. ${ }^{53}$

In his article on Brexit a year later, the day before the UK's snap election of 8 June 2017 Thomas Frank visited Wakefield in West Yorkshire,

The history of this part of England traces the history of industrialization, its rise and its fall. With coal and steel and textiles, Yorkshire witnessed the beginning of the industrial revolution 200 years ago. With politics and organizing, it is a place where the English working class came into its own. Then, with Margaret Thatcher and the big free-market beat down of the 1980 s, this was the first corner of the western world to see how it would all come crashing down. Last year's referendum on the European Union was a hint of what comes next, and this time the hindmost were in the forefront. Like much of the rest of northern England, Wakefield voted to leave, and its residents did so by $66 \% .^{54}$

Frank's assessment of Wakefield is very accurate, as is his précis of recent English economic and social history. In the 40 years since the arrival of Thatcherism, the UK has been one of the two countries most at the forefront of undiluted neoliberalism, the other being the US. For London and the South East to some extent, this has been felt as the financialization and deregulation of the economy and like everywhere else, privatization of publicly owned industries, and especially now in the late-2010s, outsourcing of public services, internal markets in what technically remain public services but the provision of their delivery put out to tender, so "not privatization" as such.

In places like Wakefield and Stoke-on-Trent, and other formerly industrial areas predominantly in the North and Midlands - there is little now but structural unemployment and chronic underemployment in insecure minimum wage jobs, as such it is one of the contentions of this article that Brexit was and is in large part a displacement of class anger and consciousness. Besides right-wingers many of them Tory MPs whose lifework has been "Euroskepticism" and the UK leaving the EU, and all of its earlier incarnations: the European Community (EC), the European Economic Community (EEC), or even ever having joined the Common Market in $1973,{ }^{55}$ there is the 
blunted and inchoate rage of places that may as well not exist in the minds of The City or the other enclaves of The Capital inhabited by economic and political elites, including Westminster.

The referendum on UK EU membership effectively became a referendum on immigration in places like Stokeon-Trent and Wakefield, meaning the displacement of working-class anger onto economic migrants Polish migrant workers doing minimum wage jobs in Amazon fulfilment centres the populations of Stoke and Wakefield were not themselves doing "explains" quotidian miseries by "Pointing sideways, kicking downward" rather than people looking up to those above them who in large part are responsible for and profit from these same miseries.

\section{| Conclusion: searching for the comprehension of practice}

This article has sought to compare and contrast the similarities between Trump's populist presidency and the confused populism of Brexit, tracing the historical background of both examples. The UK leaving the EU on March 29 was postponed until April 12, but this has now been moved to October 31, and it is now looking quite likely like it will not happen at all. The embattled prime minister Theresa May continues to run down the clock claiming she is "negotiating a deal with Brussels," suffering a Vote of No Confidence by her party as leader but it closing ranks as it always does, in enough of a show of strength that she survived: 200 having Confidence to 117 having No Confidence ${ }^{56}$ in her, she then survived a No Confidence vote by parliament itself in her as prime minister but survived 325 to $306,{ }^{57}$ the Conservative Party properly closing ranks to magically show Confidence in her and avoid a general election which would have been triggered had enough MPs voted "Aye" to the No Confidence motion.

In the past three months, the absurdities of the UK leaving the EU and all of the consequences ${ }^{58}$ this would have, have begun to become apparent to many who had previously been indifferent to the issue. ${ }^{59}$ The claims of the prime minister to "want a good deal "with the EU but refusing to rule out "no deal" which really would be cataclysmic for the UK are disingenuous, to say the least, and indeed it should be added, Machiavellian. "No deal" would mean the UK crashing out of the EU without any agreement on terms for trade with it or any imports or exports which pass through it, relying on World Trade Organization (WTO) rules which also is unsurprisingly the long-favored choice of right-wing Brexiters in the Tory party, who prefer to claim otherwise as they play their own free-market fantasy version of Game of Thrones. As of April 2019, an emergency Bill to make "No Deal" impossible was voted through by the House of Commons by one vote: 313 Ayes to 312 Noes, ${ }^{60}$ and has also been cleared by the House of Lords with amendments, meaning the long-held enthusiasm of Brexiters for the UK to leave the EU without any deal being agreed cannot happen.

In April 2019 in the UK elites denounce anyone opposed to Brexit as an "elitist," and in the US the Trump presidency believes it can win a second term, despite America's divisions having been widened and deepened since he won the 2016 presidential election and assumed office at the start of 2017. The title of this article is Taking Back Control of Nothing: Elites Denouncing Elites to Mobilize Populism in the Service of Power - from NAFTA to Trump, Brexit and the EU and this it must be said, is an ongoing process of populist mobilization from above, in which those same elites of the title make believe that inchoate displaced class anger can be channeled into denouncing the EU and the campaign to leave, as well as selectively denouncing those other elites of the title - not least their number in The City or Mayfair Hedge Funds - with a reactionary and severely blunted class edge, carefully stopping short of ever putting this explicitly in terms of social stratification.

The critique of the absurdities of 2019 in which right-wing populism is mobilized from above by elites in the service of power to divert and mystify class anger as a way of shoring up that power is the task of our times, and could be defined in paraphrasing the eighth thesis of the Theses on Feuerbach, ${ }^{61}$ searching for the comprehension of practice.

The subjects of this article Trump and Brexit can be seen as delayed responses to NAFTA and neoliberal globalization in times of crisis. In such times of crisis those who would develop and apply the materialist method theoretically and practically as praxis are aware of the odds they face, but the foremost task of our urgent present which this article has endeavored to contribute to is formulating its critique, nothing more overwhelming, nothing more daunting, nothing less. 


\section{Endnotes}

1. 'From rust belt to mill towns: a tale of two voter revolts' Thomas Frank in The Guardian 7 June 2017 https://www.theguardian.com/politics/2017/jun/07/ from-rust-belt-to-mill-towns-a-tale-of-two-voterrevolts-thomas-frank-us-and-uk-elections

2. This is from Adam Smith (1776) in The Wealth of Nations who Noam Chomsky paraphrases in his 1993 article on NAFTA "All for ourselves, and nothing for other people, seems, in every age of the world, to have been the vile maxim of the masters of mankind." Book III: On the Different Progress of Opulence in Different Nations Chapter IV: How the Commerce of the Towns Contributed to the Improvement of the Country

3. Chomsky, N. (1993) "Notes of NAFTA: The Masters of Man" https://www.marxists.org/reference/archive/ smith-adam/works/wealth-of-nations/book03/ch04. htm in The Nation March 1993 on https://chomsky. info/199303_/

4. Good concise introductions to the subject include Pierre Bourdieu (1998), "Utopia of endless exploitation: The essence of neoliberalism" Le Monde Diplomatique, available at: http://www.mondediplo. com/1998/12/08bourdieu/ David Harvey (2005), A Brief History of Neoliberalism (Oxford: Oxford University Press); Manfred B. Steger and Ravi K. Roy (2010), Neoliberalism: A Very Short Introduction (Oxford: Oxford University Press)

5. Chomsky, N \& Barsamian, D. (1994) NAFTA and GATT -- who benefits? in The Prosperous Few and the Restless Many (Berkley: Odonian Press)

6. Some useful introductions to the subject are Ellwood, W. (2002) The No-Nonsense Guide to Globalization (London: Verso in association with New Internationalist Publications) See also Bauman, Z. (1998) Globalization: The Human Consequences (Cambridge: Polity)

7. "Twenty Years Later, Nafta Remains a Source of Tension," Julian Aguiladerc in The New York Times 7 December 2012 https://www.nytimes. com/2012/12/07/us/twenty-years-later-nafta-remainsa-source-of-tension.html

8. "Can liberals please work out how to win back the working class?' Thomas Frank in The Guardian 27 July 2018 https://www.theguardian.com/ commentisfree/2018/jul/27/liberals-donald-trumprightwing-populism

9. "19 outlandish conspiracy theories Donald Trump has floated on the campaign trail and in the White House", Maxwell Tani, Michal Kranz and John Haltiwnger in Business Insider September 132018 https://www. businessinsider.com/donald-trump-conspiracytheories-2016-5? $\mathrm{r}=\mathrm{US \& IR}=\mathrm{T}$
10. Fukuyama, F. (1989), “The End of History?" The National Interest (Summer 1989), available at: http:// www.wesjones.com/eoh, Fukuyama, F. (1992), The End of History and the Last Man (Harmondsworth: Penguin)

11. An excellent critical edited collection on the "post-political" is Wilson, J. and Swyngedouw, E. eds. (2015), The Post-Political and its Discontents: Spaces of Depoliticisation, Spectres of Radical Politics (Edinburgh: Edinburgh University Press)

12. St.Clair J. (1999) “WTO Crackdown: It's a Gas, Gas, Gas!" in Counterpunch https://www.counterpunch. org/2014/12/05/seattle-diary-its-a-gas-gas-gas/

13. Notes from Nowhere collective (2003) We are Everywhere - The Irresistible Rise of Global AntiCapitalism (London: Verso) Kingsnorth, P. (2004) One No, Many Yeses: A Journey to the Heart of the Global Resistance Movement (London: Free Press)

14. Chomsky ibid

15. The database of primary sources at the University of Washington in 2019 is an invaluable resource for anyone wanting to understand the anti-WTO summit protests of 20 years ago in November and December 1999 WTO Seattle Collection, University Libraries, University of Washington, which heralded the "summit crashing" mass mobilizations of the early-2000s https://content.lib.washington.edu/wtoweb/index. html

16. 'What We Didn't Learn From the Bear Stearns Collapse', Barry Ritholtz Bloomberg, 19 March 2018 https://www.bloomberg.com/opinion/articles/2018 -03-19/what-we-didn-t-learn-from-the-bear-stearnscollapse

17. "WaMu is largest U.S. bank failure," Elinor Comlay, Jonathan Stempel, Reuters September 26, 2008, https:// www.reuters.com/article/us-washingtonmutualjpmorgannews 1/wamu-is-largest-u-s-bank-failureidUSTRE48P05I20080926

18. "The Politics of Punishment: Greece Is Being Destroyed by Europe and Austerity Orthodoxy", Sean Nevins, MPN News https://www.mintpress news.com/the-politics-of-punishment-greeceis-being-destroyed-by-europe-and-austerityorthodoxy/208014/

19. "Protesters Block London's Financial District" Landon Thomas Jr. in The New York Times April 1 2009 https://www.nytimes.com/2009/04/02/world/ europe/02protest.html

20. 'G20 protests: riot police clash with demonstrators' Sam Jones, Jenny Percival, and Paul Lewis in The 
Guardian 1 April 2009 https://www.theguardian.com/ world/2009/apr/01/g20-summit-protests

21. "Unorthodox Marxist" is ironic wordplay to differentiate from orthodox Marxism the ideology infused with Leninism as beloved by the old left, by which can be understood the orthodox/conservative/ standard left of parties and sects, which is so far from Marxism the Critical Theory, it resembles more a pyramid scheme or religion complete with starry-eyed true believers bringing the good news of a get-richquick-scheme or reciting the scriptures of the One True Faith, complete with anyone critical of scams cast as 'holding you back' from getting rich quick, or heretics and unbelievers committing the ultimate sin of rejecting blind faith.

22. "The White House revolving door: Who's gone?" BBC News, 13 February 2019 https://www.bbc.co.uk/ news/world-us-canada-39826934

23. "You're fired! I quit! The major Trump administration departures," Jamiles Lattrey and Julia Carrie Wong https://www.theguardian.com/us-news/2018/mar/07/ donald-trump-white-house-resignations-firings-full-list

24. "The 567 People, Places and Things Donald Trump Has Insulted on Twitter: A Complete List”, Jasmine C. Lee \& Kevin Quiley Updated February 202019 https:// www.nytimes.com/interactive/2016/01/28/upshot/ donald-trump-twitter-insults.html

25. "Understanding the appeal of Donald Trump," Deakin University https://this.deakin.edu.au/society/ understanding-the-appeal-of-donald-trump

26. Ibid

27. "US election 2016: Donald Trump thanks poorly educated" BBC News, 24 February 2016 https://www. bbc.co.uk/news/av/election-us-2016-35648058/uselection-2016-donald-trump-thanks-poorly-educated

28. Christian Garland states "It needn't be true as long as it's believable: manipulating data to strategize propaganda in the era of 'alternative facts" in Discovering Society DS55, April 032018 https:// discoversociety.org/2018/04/03/it-neednt-be-true-aslong-as-its-believable-manipulating-data-to-strategizepropaganda-in-the-era-of-alternative-facts/

29. Ibid

30. Quoted in ibid

31. Quoted in ibid

32. Ibid

33. "We're not changing any stories: Trump's week of contradiction," Tom McCarthy The Guardian 5 May 2018 https://www.theguardian.com/us-news/2018/ may/05/donald-trump-stormy-daniels-rudy-giulianiweek-of-contradiction
34. The concept of "Alternative facts" was of course coined by Trump's senior aide Kelly-Anne Conway, "You're saying it's a falsehood [...] Sean Spicer, our press secretary, gave alternative facts to that" 'Donald Trump's presidential counselor Kellyanne Conway says Sean Spicer gave 'alternative facts' at first press briefing' Rachel Revesz in The Independent 22 January 2017 https://www.independent.co.uk/news/ world/americas/kellyanne-conway-sean-spiceralternative-facts-lies-press-briefing-donald-trumpadministration-a7540441.html

35. "Raw hatred": why the 'incel' movement targets and terrorizes women", Zoe Williams in The Guardian 25 April 2018 https://www.theguardian.com/world/ 2018/apr/25/raw-hatred-why-incel-movementtargets-terrorises-women

36. "Nearly 50,000 sign petition to ban pro-rape pickup artist" Damien Gayle in The Guardian 2 February 2016 https://www.theguardian.com/uk-news/2016/ $\mathrm{feb} / 02 / 50000$-sign-petition-to-ban-events-by-pickup-artist-and-legal-advocate

37. "One dead after car rams into anti-fascist protesters in Charlottesville" - video report The Guardian 13 August 2017 https://www.theguardian.com/us-news/ video/2017/aug/13/fatality-car-attack-anti-fascistwhite-supremacist-rally-charlottesville-video-report

38. "Charlottesville: Trump reverts to blaming both sides including violent alt-left" Ben Jacobs and Oliver Laughland in The Guardian 16 August 2017 https:// www.theguardian.com/us-news/2017/aug/15/ donald-trump-press-conference-far-right-defendscharlottesville

39. "White supremacist who drove into a Charlottesville crowd sentenced to life in prison" James Coaston and P.J. Lockhart vox.com 11 December 2018 https:// www.vox.com/2018/12/7/18131240/unite-the-rightmurder-heather-heyer-james-fields-charlottesvillelife-sentence

40. "Donald Trump: I could shoot somebody and I wouldn't lose any voters" Reuters quoted in The Guardian 24 January 2016 https://www.theguardian. com/us-news/2016/jan/24/donald-trump-says-hecould-shoot-somebody-and-still-not-lose-voters

41. "Four More Years: The Trump reelection nightmare and how we can stop it" Thomas Frank in Harper's Magazine, February 252019 https://harpers.org/ archive/2018/04/four-more-years-2/

42. Astonishingly, one of these three newspapers - the Daily Express, Daily Mail, and The Sun - the Daily Mail ran the headlines "Enemies of the People" - for the three judges who ruled that the government would need the consent of parliament to give notice of Brexit, and "Crush the Saboteurs" - for those MPs and Peers opposed to Brexit. 
43. EU Referendum Results, BBC News https://www. bbc.co.uk/news/politics/eu_referendum/results

44. "The country I walked through deserves better than Brexit”, Mike Carter in The Guardian 11 February 2019 https://www.theguardian.com/commentisfree/2019/ feb/11/england-brexit-broken-neoliberalism

45. "Thatcherism redux" refers to the "updated" version of Thatcherism applied by the coalition led by David Cameron, which sought to "re-activate" the policies of Margaret Thatcher, British Conservative prime minister throughout the 1980s.

46. "Benefit sanctions: the 10 trivial breaches and administrative errors" Patrick Butler in The Guardian 23 March 2015 https://www.theguardian.com/ society $/ 2015 / \mathrm{mar} / 24 /$ benefit-sanctions-trivialbreaches-and-administrative-errors, "David Webster: Benefit sanctions should be a thing of the past", Patrick Butler in The Guardian 1 August 2017 https://www. theguardian.com/society/2017/aug/01/benefitsanctions-thing-of-past-david-webster

47. "Tory" is the everyday term in the UK for the Conservative \& Unionist Party, derived from the Irish Gaelic word for thief.

48. UK Population Live 66,959,016, Worldometers http://www.worldometers.info/world-population/ukpopulation/

49. Table 2 Electoral registers, 1 December 2016 Parliamentary electors, Constituent countries of the United Kingdom parliamentary constituencies, Office for National Statistics https://www.ons.gov. uk/peoplepopulationandcommunity/elections/ electoralregistration/datasets/electoralstatisticsforuk

50. Worldometers http://www.worldometers.info/ world-population/uk-population/

51. "Show this chart to anyone who says Brexit is the 'will of the British people', Joe Vesey-Byrne in The Independent 29 March 2017 https://www.indy100. com/article/brexit-leave-remain-52-48-per-cent-voterturnout-electoral-register-charts-7399226

52. "Final Say: More than $1.4 \mathrm{~m}$ additional young people could vote in new Brexit referendum", Lzzy Buchan in The Independent 28 July 2018 https://www.independent. co.uk/news/uk/politics/final-say-brexit-latest-youngvoters-second-referendum-remain-poll-a8467631.html

53. "Death of $1.5 \mathrm{~m}$ oldsters could swing second Brexit vote, says Ian McEwan" Dan Roberts in The Independent, 13 May 2017 https://www.theguardian. $\mathrm{com} /$ politics $/ 2017 / \mathrm{may} / 12 / 15 \mathrm{~m}$-oldsters-in-theirgraves-could-swing-second-eu-vote-says-ian-mcewan

54. "From rust belt to mill towns: a tale of two voter revolts" Thomas Frank in The Guardian 7 June 2017 https://www.theguardian.com/politics/2017/jun/07/ from-rust-belt-to-mill-towns-a-tale-of-two-voterrevolts-thomas-frank-us-and-uk-elections

55. The UK joined the Common Market on January 1 1973 under the Conservative Prime Minister Edward Heath. In 1975 the United Kingdom European Communities membership referendum or Common Market referendum and EEC membership referendum returned a vote in support of continued UK membership of the Common Market of $67.23 \%$ against $32.77 \%$ in favor of leaving.

56. "Theresa May survives confidence vote of Tory MPs”, BBC News 12 December 2018 https://www.bbc. co.uk/news/uk-politics-46547246

57. "May's government survives no-confidence vote" BBC News 16 December 2018 https://www.bbc.co.uk/ news/uk-politics-46899466

58. Scotland and Northern Ireland voted "Remain" and by $10 \%$ margins but are facing being steamrollered by Westminster, and dragged out of the EU regardless of these results or 20 years of devolution. The Peace Process in Northern Ireland first agreed in 1998 after painstaking negotiation now faces being jeopardized thanks to the proposed "Hard Border" with Ireland, and the UK's intransigence over there being a 'backstop' to allow a frictionless border between the two countries.

59. "Economy could be $9 \%$ weaker under no-deal Brexit, the government says" Lisa O'Carroll in The Guardian 26 February 2019 https://www.theguardian. $\mathrm{com} /$ politics $/ 2019 / \mathrm{feb} / 26 /$ economy-could-shrinkby-9-percent-under-no-deal-brexit-governmentsays? fbclid =IwAR34_m $8 \mathrm{HsIdi} 8 \mathrm{yWZiuw} 1 \mathrm{p}$ T8dkEvY6L9E1b7rRvyAK4WSAlYZbMho4VZ8nWk

60. "Brexit: a bill to prevent no-deal passes Commons by one vote", Jessica Elgot in The Guardian 4 April 2019 https://www.theguardian.com/politics/2019/apr/03/ mps-pass-motion-to-debate-article-50-extension-byone-vote

61. Marx, K. and Engels, F. (1845) Theses on Feuerbach VIII "All social life is essentially practical. All mysteries which lead theory to mysticism find their rational solution in human practice and in the comprehension of this practice." https://www.marxists.org/archive/ marx/works/1845/theses/theses.htm 


\section{References}

"19 outlandish conspiracy theories Donald Trump has floated on the campaign trail and in the White House," Maxwell Tani, Michal Kranz and John Haltiwnger in Business Insider Sep. 13, 2018 https://www.businessinsider.com/ donald-trump-conspiracy-theories-2016-5? $\mathrm{r}=\mathrm{US} \& \mathrm{IR}=\mathrm{T}$

Bauman, Z. (1998) Globalization: The Human Consequences (Cambridge: Polity)

Benefit sanctions: the 10 trivial breaches and administrative errors" Patrick Butler in The Guardian 23 March 2015 https://www.theguardian.com/society/2015/mar/24/ benefit-sanctions-trivial-breaches-and-administrative-errors

Bourdieu, P. (1998), "Utopia of endless exploitation: The essence of neoliberalism" Le Monde Diplomatique http://www. mondediplo.com/1998/12/08bourdieu/

"Brexit: a bill to prevent no-deal passes Commons by one vote", Jessica Elgot in The Guardian 4 April 2019 https://www.theguardian.com/politics/2019/apr/03/ mps-pass-motion-to-debate-article-50-extension-by-one-vote

"Can liberals please work out how to win back the working class?" Thomas Frank in The Guardian 27 July 2018 https:// www.theguardian.com/commentisfree/2018/jul/27/ liberals-donald-trump-rightwing-populism

"Charlottesville: Trump reverts to blaming both sides including violent alt-left" Ben Jacobs and Oliver Laughland The Guardian 16 August 2017 https://www.theguardian.com/us-news/2017/ aug/15/donald-trump-press-conference-far-right-defends-charlottesville

Chomsky, N. (1993) Notes of NAFTA: The Masters of Man in The Nation March 1993 on https://chomsky.info/199303_/

----. \& Barsamian, D. (1994) NAFTA and GATT -- who benefits? in The Prosperous Few and the Restless Many (Berkley: Odonian Press)

"David Webster: Benefit sanctions should be a thing of the past", Patrick Butler in The Guardian 1 August 2017 https://www.theguardian.com/society/2017/aug/01/ benefit-sanctions-thing-of-past-david-webster

"Death of $1.5 \mathrm{~m}$ oldsters could swing second Brexit vote, says Ian McEwan" Dan Roberts in The Independent 13 May 2017 https://www.theguardian.com/politics/2017/may/12/15moldsters-in-their-graves-could-swing-second-eu-vote-says-ianmcewan

"Donald Trump: I could shoot somebody and I wouldn't lose any voters" Reuters quoted in The Guardian 24 January 2016 https://www.theguardian.com/us-news/2016/jan/24/donaldtrump-says-he-could-shoot-somebody-and-still-not-lose-voters
“Donald Trump's presidential counsellor Kellyanne Conway says Sean Spicer gave "alternative facts" at first press briefing" Rachel Revesz in The Independent 22 January 2017 https:// www.independent.co.uk/news/world/americas/kellyanne-conway-sean-spicer-alternative-facts-lies-press-briefing-donald-trump-administration-a7540441.html

"Economy could be $9 \%$ weaker under no-deal Brexit, the government says" Lisa O'Carroll in The Guardian 26 February 2019 https://www.theguardian.com/politics/2019/feb/26/economy-could-shrink-by-9-percent-under-no-deal-brexit-government-says?fbclid=IwAR34_m8HsIdi8yWZiuw1pT8dkEvY6L9E1b7rRvyAK4WSAlYZ̄bMho4VZ8nWk

Ellwood, W. (2002) The No-Nonsense Guide to Globalization (London: Verso in association with New Internationalist Publications)

EU Referendum Results, BBC News https://www.bbc.co.uk/ news/politics/eu_referendum/results

"Final Say: More than $1.4 \mathrm{~m}$ additional young people could vote in new Brexit referendum", Lizzy Buchan in The Independent 28 July 2018 https://www.independent.co.uk/news/uk/ politics/final-say-brexit-latest-young-voters-second-referendum-remain-poll-a8467631.html

"Four More Years: The Trump reelection nightmare and how we can stop it" Thomas Frank in Harper's Magazine, February 252019 https://harpers.org/archive/2018/04/ four-more-years-2/

"From rust belt to mill towns: a tale of two voter revolts" Thomas Frank in The Guardian 7 June 2017 https://www.theguardian.com/politics $/ 2017 /$ jun/07/from-rust-belt-to-mill-townsa-tale-of-two-voter-revolts-thomas-frank-us-and-uk-elections

Fukuyama, F. (1989), “The End of History?" in The National Interest (Summer 1989), available at: http://www.wesjones. com/eoh

-... (1992), The End of History and the Last Man (Harmondsworth: Penguin)

"G20 protests: riot police clash with demonstrators" Sam Jones, Jenny Percival and Paul Lewis in The Guardian 1 April 2009

https://www.theguardian.com/world/2009/apr/01/ g20-summit-protests

Harvey, D. (2005), A Brief History of Neoliberalism (Oxford: Oxford University Press)

"It needn't be true as long as it's believable: manipulating data to strategize propaganda in the era of 'alternative facts' Christian Garland in Discovering Society DS55, April 032018 https:// discoversociety.org/2018/04/03/it-neednt-be-true-as-long-asits-believable-manipulating-data-to-strategize-propaganda-inthe-era-of-alternative-facts/ 
Kingsnorth, P. (2004) One No, Many Yeses: A Journey to the Heart of the Global Resistance Movement (London: Free Press)\}

Manfred B. Steger and Ravi K. Roy (2010), Neoliberalism: A Very Short Introduction (Oxford: Oxford University Press)

Marx, K. and Engels, F. (1845) Theses on Feuerbach VIII https:// www.marxists.org/archive/marx/works/1845/theses/theses. htm

"May's government survives no-confidence vote” BBC News 16 December 2018 https://www.bbc.co.uk/news/ uk-politics-46899466

"Nearly 50,000 sign petition to ban pro-rape pick-up artist" Damien Gayle in The Guardian 2 February 2016 https://www. theguardian.com/uk-news/2016/feb/02/50000-sign-petitionto-ban-events-by-pick-up-artist-and-legal-advocate

Notes from Nowhere collective We are Everywhere - The Irresistible Rise of Global Anti-Capitalism (London: Verso)

"One dead after car rams into anti-fascist protesters in Charlottesville” - video report The Guardian 13 August 2017 https://www.theguardian.com/us-news/video/2017/aug/13/ fatality-car-attack-anti-fascist-white-supremacist-rally-charlottesville-video-report

“Protesters Block London's Financial District" Landon Thomas Jr. in The New York Times April 12009 https://www.nytimes. com/2009/04/02/world/europe/02protest.html

"Raw hatred: why the incel movement targets and terrorizes women", Zoe Williams in The Guardian 25 April 2018 https://www.theguardian.com/world/2018/apr/25/ raw-hatred-why-incel-movement-targets-terrorises-women

"Show this chart to anyone who says Brexit is the "will of the British people", Joe Vesey-Byrne in The Independent 29 March 2017 https://www.indy100.com/article/brexit-leave-remain52-48-per-cent-voter-turnout-electoral-register-charts-7399226

Smith, A. (1776) The Wealth of Nations Book III: On the Different Progress of Opulence in Different Nations Chapter IV: How the Commerce of the Towns Contributed to the Improvement of the Country https://www.marxists.org/ reference/archive/smith-adam/works/wealth-of-nations/ book03/ch04.htm

St.Clair J. (1999) "WTO Crackdown: It's a Gas, Gas, Gas!" in Counterpunch https://www.counterpunch.org/2014/12/05/ seattle-diary-its-a-gas-gas-gas/

Table 2 Electoral registers, 1 December 2016 Parliamentary electors, Constituent countries of the United Kingdom parliamentary constituencies, Office for National Statistics https:// www.ons.gov.uk/peoplepopulationandcommunity/elections/ electoralregistration/datasets/electoralstatisticsforuk

“The 567 People, Places and Things Donald Trump Has Insulted on Twitter: A Complete List", Jasmine C. Lee \& Kevin Quiley Updated February 202019 https://www.nytimes.com/interactive/2016/01/28/upshot/donald-trump-twitter-insults.html
"The country I walked through deserves better than Brexit", Mike Carter in The Guardian 11 February 2019 https:// www.theguardian.com/commentisfree/2019/feb/11/ england-brexit-broken-neoliberalism

"The Politics of Punishment: Greece Is Being Destroyed by Europe and Austerity Orthodoxy", Sean Nevins, MPN News https://www.mintpressnews.com/the-politics-of-punishment-greece-is-being-destroyed-by-europe-and-austerity-orthodoxy/208014/

“The White House revolving door: Who's gone?” BBC News, 13 February 2019 https://www.bbc.co.uk/news/ world-us-canada-39826934

“Theresa May survives confidence vote of Tory MPs", BBC News 12 December 2018 https://www.bbc.co.uk/news/ uk-politics- 46547246

“Twenty Years Later, Nafta Remains a Source of Tension", Julian Aguiladerc in New York Times 7 December 2012 https:// www.nytimes.com/2012/12/07/us/twenty-years-later-naftaremains-a-source-of-tension.html

"Understanding the appeal of Donald Trump", Deakin University https://this.deakin.edu.au/society/ understanding-the-appeal-of-donald-trump

University of Washington "WTO Seattle Collection", University Libraries, https://content.lib.washington.edu/wtoweb/index. html

UK Population Live 66,959,016, Worldometers http://www. worldometers.info/world-population/uk-population/

"US election 2016: Donald Trump thanks poorly educated" BBC News, 24 February 2016 https:// www.bbc.co.uk/news/av/election-us-2016-35648058/ us-election-2016-donald-trump-thanks-poorly-educated

"WaMu is largest U.S. bank failure", Elinor Comlay, Jonathan Stempel, Reuters September 262008 https://www.reuters. com/article/us-washingtonmutual-jpmorgannews $1 /$ wamu-is-largest-u-s-bank-failure-idUSTRE48P05I20080926

"We're not changing any stories: Trump's week of contradiction", Tom McCarthy in The Guardian 5 May 2018 https://www. theguardian.com/us-news/2018/may/05/donald-trumpstormy-daniels-rudy-giuliani-week-of-contradiction

"What We Didn't Learn From the Bear Stearns Collapse", Barry Ritholtz for Bloomberg 19 March 2018 https:// www.bloomberg.com/opinion/articles/2018-03-19/ what-we-didn-t-learn-from-the-bear-stearns-collapse

"White supremacist who drove into a Charlottesville crowd sentenced to life in prison" James Coaston and P.J. Lockhart vox.com 11 December 2018 https://www.vox. com/2018/12/7/18131240/unite-the-right-murder-heatherheyer-james-fields-charlottesville-life-sentence

Wilson, J. and Swyngedouw, E. eds. (2015) The Post-Political and its Discontents: Spaces of Depoliticisation, Spectres of Radical Politics (Edinburgh: Edinburgh University Press) 
Worldometers http://www.worldometers.info/world-population/ uk-population/

"You're fired! I quit! The major Trump administration departures", Jamiles Littre and Julia Carrie Wong in The Guardian https://www.theguardian.com/us-news/2018/mar/07/ donald-trump-white-house-resignations-firings-full-list 